\title{
Activation of the NALP3 inflammasome is triggered by low intracellular potassium concentration
}

\author{
V Pétrilli ${ }^{1}$, S Papin ${ }^{1}$, C Dostert ${ }^{1}$, A Mayor ${ }^{1}$, F Martinon ${ }^{1,2}$ and J Tschopp ${ }^{\star, 1}$
}

Inflammasomes are Nod-like receptor(NLR)- and caspase-1-containing cytoplasmic multiprotein complexes, which upon their assembly, process and activate the proinflammatory cytokines interleukin (IL)-1 $\beta$ and IL-18. The inflammasomes harboring the NLR members NALP1, NALP3 and IPAF have been best characterized. While the IPAF inflammasome is activated by bacterial flagellin, activation of the NALP3 inflammasome is triggered not only by several microbial components, but also by a plethora of danger-associated host molecules such as uric acid. How NALP3 senses these chemically unrelated activators is not known. Here, we provide evidence that activation of NALP3, but not of the IPAF inflammasome, is blocked by inhibiting $\mathrm{K}^{+}$efflux from cells. Low intracellular $\mathrm{K}^{+}$is also a requirement for NALP1 inflammasome activation by lethal toxin of Bacillus anthracis. In vitro, NALP inflammasome assembly and caspase-1 recruitment occurs spontaneously at $\mathrm{K}^{+}$concentrations below $90 \mathrm{mM}$, but is prevented at higher concentrations. Thus, low intracellular $\mathrm{K}^{+}$may be the least common trigger of NALP-inflammasome activation.

Cell Death and Differentiation (2007) 14, 1583-1589; doi:10.1038/sj.cdd.4402195; published online 29 June 2007

Interleukin (IL)-1 $\beta$ is a highly inflammatory cytokine, whose production is tightly controlled by at least three distinct steps. ${ }^{1}$ The initial event (priming) involves the production of the prolL$1 \beta$ protein (p35), for example, by activation of various Toll-like receptors (TLRs). Then the cleavage of the precursor prolL- $1 \beta$ by caspase- 1 results in the production of active $\mathrm{IL}-1 \beta$ protein ( $\mathrm{p} 17$ ), which, in the third step, is finally released into the extracellular milieu. The second step, the processing of prolL- $1 \beta$, requires the assembly and activation of a caspase-1-activating complex, the so-called inflammasome. ${ }^{2}$

The inflammasome complex consists of a NALP protein as well as the adapter protein ASC, which connects the NALP proteins to the third component, namely caspase-1. ${ }^{3}$ An exception is NALP1, which can directly bind and activate caspase- 1 and/or caspase-5 via its unique C-terminal caspase-associated recruitment (CARD) domain. ${ }^{4,5}$ The human genome harbors a repertoire of 14 NALPs, ${ }^{3}$ which all belong to the family of Nod-like receptors (NLRs). ${ }^{6-8}$ It is currently not clear how many of them form active inflammasomes, but considerable data supports a role of NALP1, 4,5 NALP2,${ }^{9}$ NALP3 ${ }^{9}$ NALP6, ${ }^{10}$ NALP $7^{11}$ and NALP $12^{12}$ in caspase-1 activation. In addition to the NALPs, another NLR member, IPAF, forms an inflammasome, which is however ASC-independent. Through its CARD domain, IPAF directly binds and activates caspase-1. ${ }^{6}$

Signals and mechanisms leading to inflammasome activation are still poorly understood. The sole activator of the IPAF inflammasome described so far is bacterial flagellin. ${ }^{13,14}$ In contrast, the NALP3 inflammasome is activated by a plethora of pathogen-associated molecular patterns (PAMPs). For example, bacterial muramyl dipeptide (MDP), ${ }^{15}$ a degradation product of the bacterial cell wall component peptidoglycans (PGN), as well as RNA of bacterial and viral origin activate NALP3. ${ }^{16,17}$ Besides these classical PAMPs, the microbial toxins nigericin (Streptomyces hygroscopicus), aerolysin (Aeromonas hydrophila), maitotoxin (Marina dinoflagellates), gramicidin (Bacillus brevis) and $\alpha$-toxin (Staphylococcus aureus) are potent NALP3 inflammasome activators. ${ }^{18-20}$ Furthermore, 'danger-associated molecular patterns or DAMPs' (non-microbial/pathogenic) such as ATP, imidazoquinoline, monosodium urate crystals (MSU) and the skin irritant trinitrochlorobenzene have been shown to induce NALP3 inflammasome activity. ${ }^{16,19,21-23}$ Similar to NALP3, the NALP1 inflammasome can be activated by MDP. ${ }^{5,15}$ Moreover, in mice activation of caspase-1 by lethal toxin of $B$. anthracis is dependent on a functional NALP1b. ${ }^{24}$

How NALPs and NALP3 in particular sense these disparate activators is not known. There are two simplistic scenarios; either each component directly interacts with NALP3 (such a mechanism has been proposed for TLRs and NALP1), or alternatively, each ligand induces a cellular stress situation that in all cases results in the activation of a cytoplasmic protein that consequently becomes a NALP3 ligand and activator. A variation of the second proposal is that the various stresses lead to a change in the intracellular ionic milieu that induces a conformational change in one of the inflammasome components and subsequent activation. This latter model is supported by existing experimental evidence. The caspase-1 activators ATP and nigericin were shown years ago to act through a mechanism dependent on potassium $\left(\mathrm{K}^{+}\right)$

\footnotetext{
'Department of Biochemistry, University of Lausanne, Chemin des Boveresses 155, Center of Immunology Lausanne, Epalinges 1066, Switzerland *Corresponding author: J Tschopp, Department of Biochemistry, University of Lausanne, Ch. des Boveresses 155, Epalinges CH-1066, Switzerland. Tel: + 4121692 5738; Fax: + 4121692 5705; E-mail: jurg.tschopp @ unil.ch

${ }^{2}$ Current address: Department of Immunology and Infectious Diseases, Harvard School of Public Health, Boston, MA 02115, USA Keywords: Inflammasome; caspase-1; IL-1 $\beta$; inflammation

Abbreviations: II-1 $\beta$, interleukin-1 $\beta$; PAMPs, pathogen-associated molecular patterns; NLRs, NOD-like receptors; MDP, muramyl-di-peptide Received 29.1.07; revised 09.5.07; accepted 31.5.07; Edited by DR Green; published online 29.6.07
} 
efflux. $^{20,25,26}$ Based on the current understanding that both nigericin and ATP activate the NALP3 inflammasome, ${ }^{19,21}$ we became interested in investigating the possibility that all known signals that activate the NALP3 inflammasome act by inducing intracellular $\mathrm{K}^{+}$efflux, thus explaining why seemingly unrelated molecules can activate the same inflammasome.

\section{Results}

Inhibition of $\mathrm{K}^{+}$efflux prevents NALP3, but not IPAF inflammasome activation. To investigate the possible role of $\mathrm{K}^{+}$in NALP3 inflammasome activation, mouse peritoneal macrophages were primed overnight with lipopolysaccharide (LPS) to induce prolL-1 $\beta$ synthesis followed by a 6-h incubation with the inflammasome-activating agents. As expected, the NALP3 activators nigericin, ATP, MSU, R837 (a synthetic imidazoquinoline compound mimicking ssDNA or SsRNA) and PGN resulted in the potent activation of the inflammasome and release of active $\mathrm{IL}-1 \beta$ and processed caspase-1 that was absent in NALP3-/- cells (Figure 1). Unexpectedly, however, we were unable to activate the inflammasome using the reported activators poly $(\mathrm{I}: \mathrm{C})$ and bacterial RNA under these conditions even after prolonged exposure (Supplementary Figure 1). ${ }^{16,17}$

$\mathrm{K}^{+}$efflux from cells induced by pore-forming toxins such as nigericin and P2X7 stimulation has been reported to be essential for triggering caspase- 1 activation. ${ }^{20,25,26}$ Consequently, activation can be specifically blocked by the addition of $130 \mathrm{mM}$ extracellular $\mathrm{K}^{+}$, but not by other cations. ${ }^{20,25}$ To test whether $\mathrm{K}^{+}$efflux is required for NALP3 inflammasome activation in general, we stimulated macrophages with several NALP3 activators in the absence or presence of $130 \mathrm{~mm}$ extracellular $\mathrm{K}^{+} .{ }^{20}$ In agreement with the previous results, ${ }^{20}$ maturation and release of caspase- 1 and IL-1 $\beta$ caused by nigericin and ATP was completely blocked when the extracellular $\mathrm{K}^{+}$was increased to $130 \mathrm{~mm}^{20,25}$ (Figure 1). The inhibitory effect of the $\mathrm{K}^{+}$-rich medium was also observed with all other inflammasome activators tested (Figures 1 and 2), with one exception, namely Salmonella typhimurium, which is known to activate the IPAF inflammasome (Figure 2b). ${ }^{27}$

In addition to the known activators of NALP3, we found live Escherichia coli potently activated the inflammasome in a NALP3-dependent manner (Figure 2a). Similar to other NALP3 activators, activation by $E$. coli was inhibited when $\mathrm{K}^{+}$efflux was blocked with increased concentrations of extracellular potassium. Lethal toxin (LT) of $B$. anthracis, which activates the NALP1 inflammasome in Balb/c mice, ${ }^{24}$ was also found to lose its IL-1 $\beta$ processing activity in the presence of high extracellular $\mathrm{K}^{+}$(Figure 2c). Thus, the dependence on low intracellular $\mathrm{K}^{+}$for activation is a characteristic of the NALP1 and NALP3 inflammasomes that is not shared by the IPAF inflammasome.

Extracellular potassium inhibits NALP3 activation in human monocytes. The requirement for low intracellular $\mathrm{K}^{+}$for NALP inflammasome activation is not a unique feature of murine cells, but was also seen in human monocytes/macrophages. When human THP1 cells were
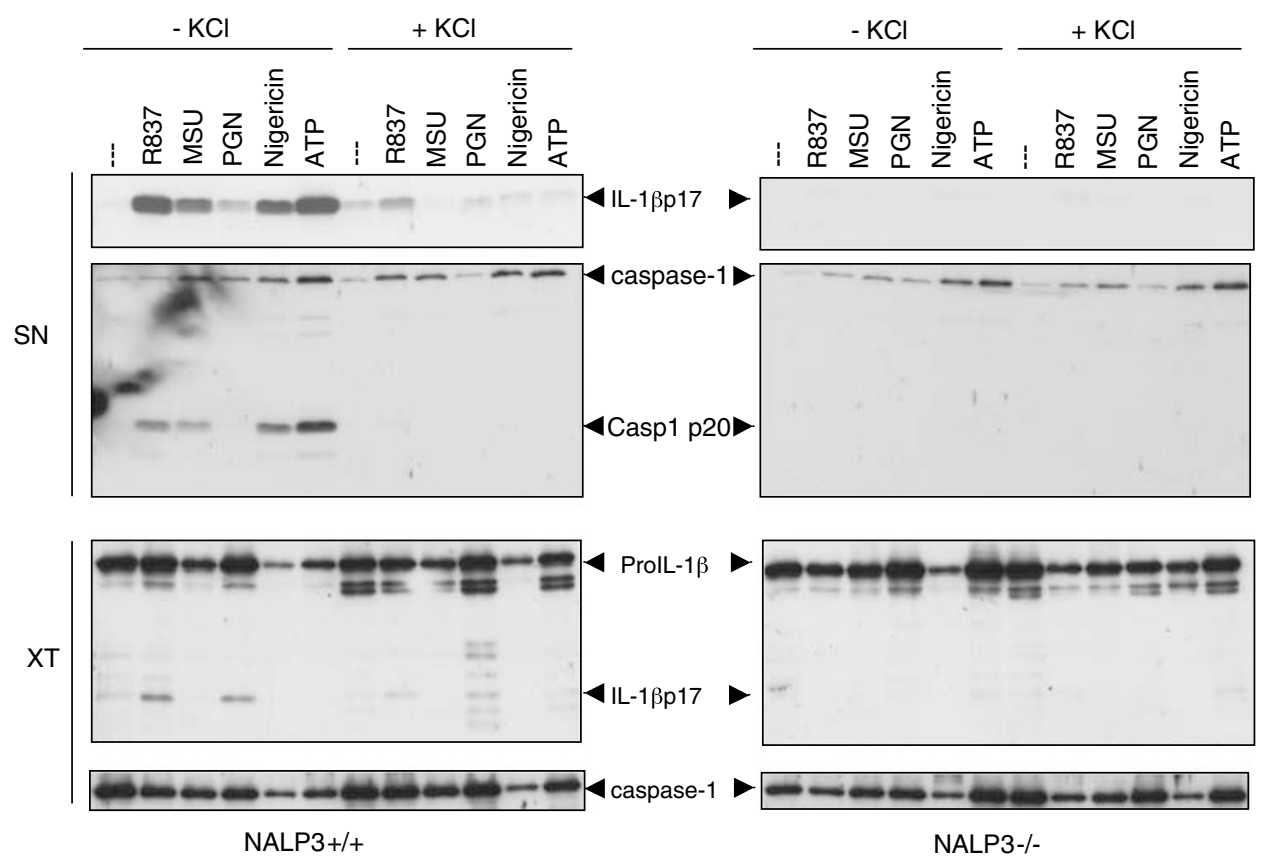

Figure 1 Maturation of IL-1 $\beta$ is blocked by extracellular potassium (KCI) in mouse macrophages. LPS-primed murine NALP3 + / + and NALP3-I- macrophages were stimulated with different reported NALP3 agonists for $6 \mathrm{~h}$ except for ATP that was added 30 min before the end of the experiment. Addition of $130 \mathrm{~mm} \mathrm{KCl} \mathrm{to} \mathrm{the} \mathrm{extracellular}$ medium blocks IL-1 $\beta$ maturation in response to NALP3 agonists. ProlL-1 $\beta$ maturation into the active 17 form and processing of caspase-1 were analyzed by Western blot of cell supernatants (SN) and extracts (XT). Note that $\mathrm{KCl}$ does not affect the pool of pro-lL-1 $\beta$ in XT. The following concentrations of agonists were added: ATP, 5 mM; nigericin, $20 \mu \mathrm{M} ; \mathrm{MSU}, 150 \mu \mathrm{g} / \mathrm{ml}$; R837, $10 \mu \mathrm{g} / \mathrm{ml} ; \mathrm{PGN}, 20 \mu \mathrm{g} / \mathrm{ml}$ 
a
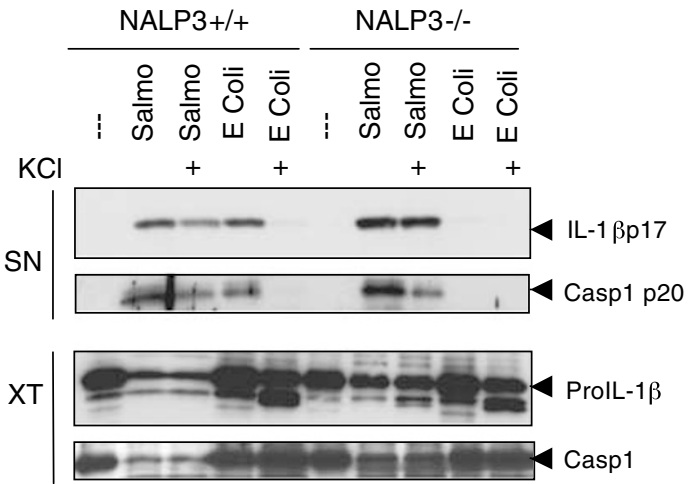

b
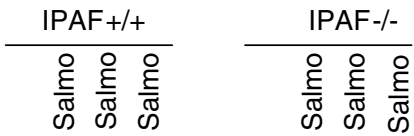

Time (min) : 90180180

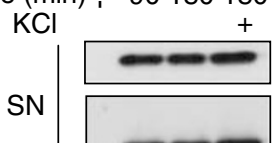

| 90180180
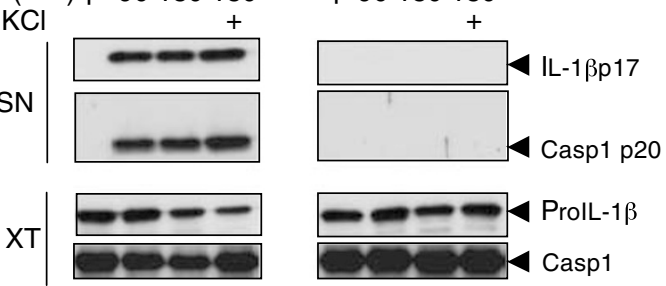

c

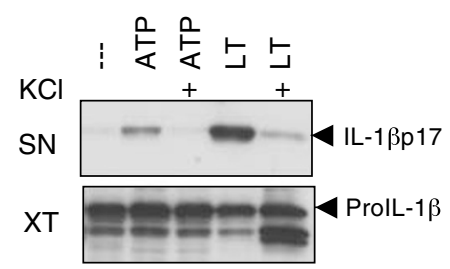

Figure 2 Inhibition of IL-1 $\beta$ maturation by extracellular potassium is specific for the NALP inflammasome. (a) NALP3 $+/+$ and $-/$ - murine macrophages were infected with $E$. coli or $S$. typhimurium for $5 \mathrm{~h}$ in the presence or the absence of $130 \mathrm{mM} \mathrm{KCl}$. (b) IPAF $+1+$ and $-1-$ macrophages were infected with $S$. typhimurium for the indicated time periods in the presence or absence of $130 \mathrm{mM}$ extracellular $\mathrm{K}^{+}$. (c) Macrophages from BALB/c mice were stimulated with ATP or $\mathrm{LT}(1 \mu \mathrm{g} / \mathrm{ml})$ in the presence or the absence of high $\mathrm{KCl}$. Maturation of pro-lL- $1 \beta$ and cleaved caspase- 1 were analyzed in cell supernatants (SN) and extracts (XT) by Western blot

stimulated for $6 \mathrm{~h}$ with $\mathrm{PGN}, \mathrm{MSU}$ or nigericin in the presence or absence of $130 \mathrm{~mm}$ extracellular $\mathrm{K}^{+}$, maturation and release of IL-1 $\beta$ was inhibited by elevated concentrations of $\mathrm{K}^{+}$in each case (Figure 3a). Akin to murine cells (Supplementary Figure 1), we were unable to activate the human inflammasomes with bacterial RNA or the synthetic RNA analog poly $(\mathrm{I}: \mathrm{C})^{16}$ (Figure $3 \mathrm{~b}$ ). To demonstrate the specificity of $\mathrm{K}^{+}$inhibition toward NALP3, we generated THP1 cells stably transfected with short hairpin RNA (shRNA) to knock-down (kd) NALP3 and ASC gene expression. ${ }^{28}$ THP1 transfectants expressing lamin-specific shRNA were used as a control cell line. IL-1 $\beta$ maturation triggered by all three investigated activators was blocked in the absence of NALP3 or ASC, although some residual activation was detected in ASCkd cells owing to incomplete $\mathrm{kd}$ of the corresponding mRNA. ${ }^{28}$ Shigella flexneri is a well-known activator of caspase-1. Like $S$. typhimurium, its pathogenesis is mediated by a type III secretion system that is detected by the IPAF activating platform. As observed for $S$. typhimurium (see Figure $2 \mathrm{~b}$ ), activation of caspase-1 in wt THP1 cells by $S$. flexneri was not inhibited by extracellular $\mathrm{K}^{+}$, nor by the absence of NALP3, demonstrating again the specificity of $\mathrm{K}^{+}$toward the NALP3 inflammasome (Figure 3c). Maturation of IL-1 $\beta$ was, however, abolished in the presence of the pan-caspase inhibitor zVAD. Interestingly, as previously described for $S$. typhimurium, $\mathrm{kd}$ of ASC resulted in a decrease in IL-1 $\beta$ production, ${ }^{27}$ suggesting the involvement of a NALP protein other than NALP1 and NALP3. $\mathrm{K}^{+}$-induced inhibition of prolL-1 $\beta$ processing was also seen in primary human monocytes (Figure 3d).

Physiological intracellular $\mathrm{K}^{+}$concentrations inhibit inflammasome assembly. To investigate the mechanism by which low intracellular potassium activates the inflammasome, we employed the in vitro inflammasome activation assay previously described by our group. ${ }^{4}$ THP1 cells lysed in a buffer containing $10 \mathrm{mM} \mathrm{KCl}$ triggers spontaneous inflammasome assembly and caspase- 1 activation in the resulting cell extracts in an ASCdependent manner, since caspase-1 activation is highly reduced in cell extracts immunodepleted for ASC. ${ }^{4}$ As shown in Figure 4, this spontaneous inflammasome activation was highly dependent on the $\mathrm{K}^{+}$concentration. When $\mathrm{K}^{+}$levels exceeded $70 \mathrm{mM}$ (Figure 4a), caspase- 1 activation did not occur. To study whether this high $\mathrm{K}^{+}$concentration affects the assembly of the inflammasome, ASC was immunoprecipitated in lysates in the absence or presence of $130 \mathrm{mM} \mathrm{K}^{+}$. While the processed form of caspase-1 (p35, CARD domain) was immunoprecipitated by ASC under low $\mathrm{K}^{+}$conditions, no caspase-1 was pulled-down in the presence of $130 \mathrm{~mm}$ (Figure 4b). Thus, physiological intracellular concentrations of $\mathrm{K}^{+}$block the recruitment of caspase- 1 to ASC possibly due to inhibition of NALP oligomerization.

The mechanism by which $\mathrm{K}^{+}$efflux induces inflammasome activation is not clear. Recently, caspase-1 activation induced by ATP stimulation was shown to be dependent on the formation of reactive oxygen species (ROS) ${ }^{29}$ We thus investigated whether ROS were involved in NALP3 inflammasome activation. To test this notion, THP1 cells were preincubated with the broad ROS inhibitor $\mathrm{N}$-acetyl-cysteine (NAC), followed by stimulation with R837 or MSU. Interestingly, NAC significantly inhibited IL-1 $\beta$ maturation in response to both stimuli (Figure 4c), suggesting that in addition to $\mathrm{K}^{+}$, ROS play a crucial role in the activation of the NALP3 inflammasome.

\section{Discussion}

The mechanism by which the various activators of the NALP3inflammasome trigger complex formation remains enigmatic. For some, such as PGN, it is feasible to propose that activation occurs via a direct interaction with the LRRs of NALP3, leading to a conformational change in NALP3 and finally to inflammasome assembly. This putative mechanism 

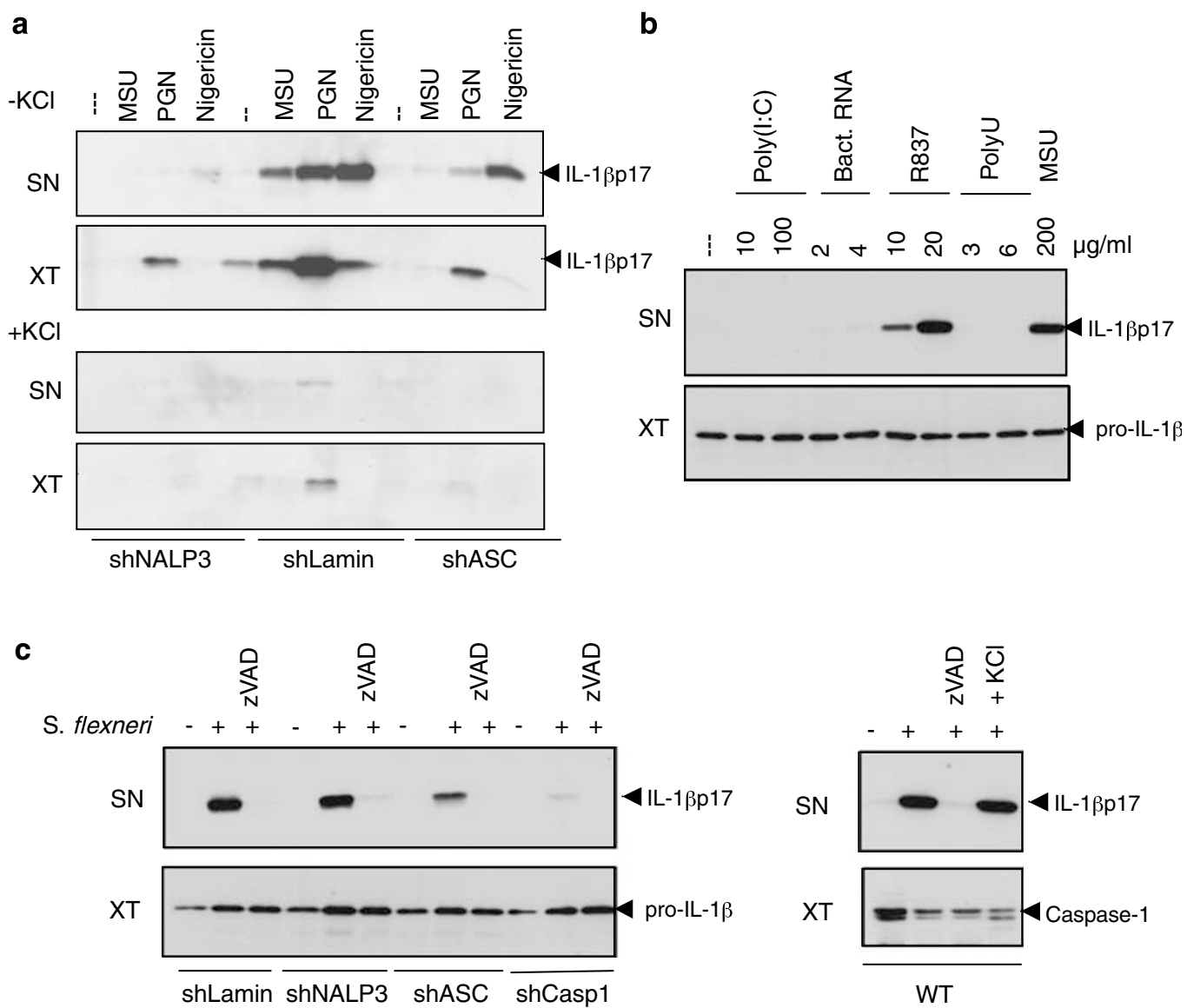

d $+\mathrm{KCl}$
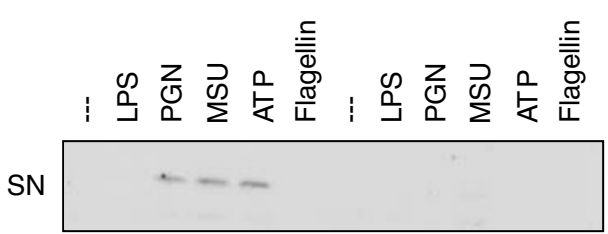

4 IL-1 $\beta$ p 177

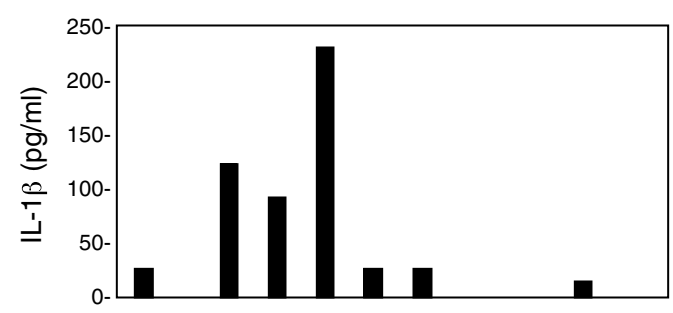

Figure 3 NALP3-inflammasome activation in human monocytes is blocked by high concentrations of extracellular KCl. (a) THP1 cells were stimulated for $6 \mathrm{~h}$ with MSU $(100 \mu \mathrm{g} / \mathrm{ml}), \mathrm{PGN}(20 \mu \mathrm{g} / \mathrm{ml})$ and nigericin $(20 \mu \mathrm{M})$ in presence (lower panel) or absence (upper panel) of $130 \mathrm{mM} \mathrm{KCl}$. (b) THP1 cells were stimulated for $6 \mathrm{~h}$ with the RNA analog R873 ((10 $\mu \mathrm{g} / \mathrm{ml})$, poly(U) $(6 \mu \mathrm{g} / \mathrm{ml})$ and bacterial RNA (4 $\mu \mathrm{g} / \mathrm{ml})$, poly:IC $(50 \mu \mathrm{g} / \mathrm{ml})$ and MSU (positive control). (c) Wild-type THP1, ASC knock-down (kd), NALP3kd and caspase-1 kd THP1 cells were infected with $S$. flexnerifor $5 \mathrm{~h}$ in the absence or presence of $130 \mathrm{~mm} \mathrm{KCl}$ or $50 \mu \mathrm{M} \mathrm{ZVAD}$. (d) Primary human monocytes were incubated for $6 \mathrm{~h}$ with LPS $(100 \mathrm{ng} / \mathrm{ml})$, PGN $(20 \mu \mathrm{g} / \mathrm{ml})$, MSU $(150 \mu \mathrm{g} / \mathrm{ml})$, ATP $(5 \mathrm{mM})$ and flagellin $(500 \mathrm{ng} / \mathrm{ml})$. As expected, addition of extracellular flagellin does not activate the inflammasome (negative control). IL-1 $\beta$ maturation was assessed in cell supernatants (SN) by Western blot and ELISA (lower panel)

is reminiscent of that proposed for TLRs, where some receptors have been shown to directly interact with their cognate ligands. ${ }^{30}$ Recently, direct binding of MDP to recombinant NALP1 was indeed demonstrated. MDP inter- acting with the LRR region of NALP1 is essential for caspase1 activation mediated by the reconstituted NALP1 inflammasome. ${ }^{5}$ These data clearly establish that NALPs can directly interact with PAMPs. 
a

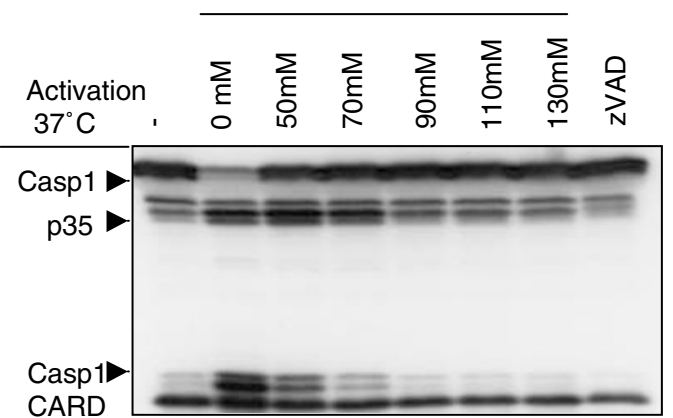

b

$$
\frac{X T}{\mathrm{KCl}} \frac{\mathrm{IP} \alpha \text {-ASC }}{\mathrm{Ctr} \mathrm{KCl}}
$$

Activation $37^{\circ} \mathrm{C} \quad 0^{\prime} 30^{\prime} 30^{\prime}$ 0' 0 ' 30' 30'
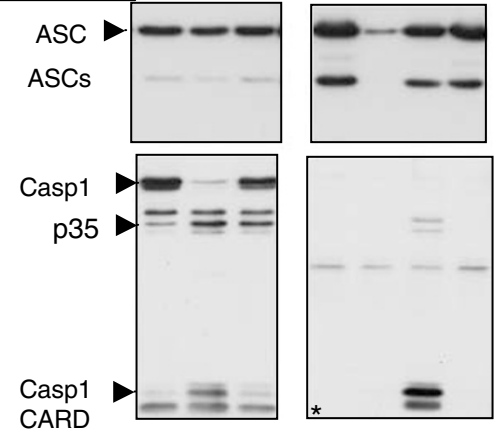

CARD

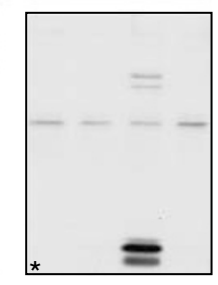

C

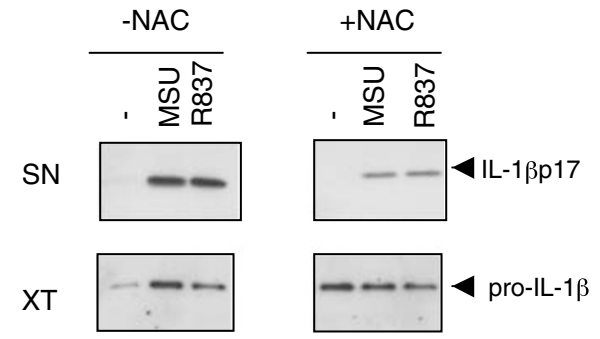

Figure 4 Potassium inhibits caspase-1 activation in vitro. (a) THP1 cell lysates were incubated for $30 \mathrm{~min}$ at $37^{\circ} \mathrm{C}$ and caspase-1 processing was assessed by Western blot analysis in the presence of different $\mathrm{KCl}$ concentrations or in the presence of $50 \mu \mathrm{M} \mathrm{zVAD}$. The anti-caspase-1 antibody used detects the processed CARD domain of caspase-1. (b) THP1 cell lysates were incubated for $30 \mathrm{~min}$ at $37^{\circ} \mathrm{C}$ in the presence or absence of $130 \mathrm{mM} \mathrm{KCl}$, followed by ASC immunoprecipitation (IP). Recruitment of caspase-1 to ASC was analyzed by Western blot. Ctr is the control IP using anti-flag antibody. (c) WT THP1 cells were pre-incubated or not with $\mathrm{N}$-acetyl-cysteine (NAC, $25 \mathrm{~mm}$ ) 5 min before stimulation with MSU $(150 \mu \mathrm{g} / \mathrm{ml})$ and R837 $(10 \mu \mathrm{g} / \mathrm{ml})$ for $6 \mathrm{~h}$

In our study, we provide evidence that the activity of all currently known NALP3 activators is blocked by inhibiting efflux of $\mathrm{K}^{+}$. Since little is known about activators of other NALPs such as NALP6 or NALP12, the assessment of the role of $\mathrm{K}^{+}$efflux in NALP inflammasomes in general is limited. Anthrax LT was shown to activate murine NALP1. Interestingly, NALP1 inflammasome activation by LT is also blocked by high extracellular $\mathrm{K}^{+}$. Human NALP1 detects, like NALP3, MDP. ${ }^{5}$ As caspase- 1 activation by PGN/MDP was inhibited by high $\mathrm{K}^{+}$, it is likely that NALP1 and NALP3 inflammasomes both require $\mathrm{K}^{+}$efflux for activation. Importantly, the activation of the inflammasome by low concentration of $\mathrm{K}^{+}$ is specific to NALP inflammasomes. Activation of the IPAF inflammasome by either Shigella or by Salmonella was not affected by high extracellular $\mathrm{K}^{+}$, indicating that the mechanism of activation of the NALP1/3 inflammasomes and the IPAF inflammasome is distinct.

The data presented here suggest a model in which the common trigger of NALP3 inflammasome activation is a decrease in physiological intracellular $\mathrm{K}^{+}$concentration $(143 \mathrm{~mm})$. This notion is in line with the observation that some of the most potent activators of the NALP3 inflammasome are known $\mathrm{K}^{+}$channels. The microbial toxins nigericin, gramicidin, maitotoxin and $\alpha$-toxin are $\mathrm{K}^{+}$channels and are all recognized to cause a marked depletion of intracellular $\mathrm{K}^{+}$. ATP acts via the $P 2 X 7$ receptor, which upon stimulation facilitates an immediate $\mathrm{K}^{+}$efflux. In addition, ouabain, which was previously shown to lead to IL-1 $\beta$ maturation, ${ }^{20}$ is an inhibitor of $\mathrm{Na}^{+}, \mathrm{K}^{+}$-ATPase. The mechanism of lowering intracellular $\mathrm{K}^{+}$levels is less evident for other activators of the NALP3 inflammasome. MSU is detected at the cell surface by CD14, a phagocyte-expressed pattern recognition receptor that functionally interacts with both TLR2 and TLR4. ${ }^{31} \mathrm{PGN}$ is also a ligand of TLR2, suggesting that TLR2 or TLR4 might change intracellular $\mathrm{K}^{+}$levels. Interestingly, TLRs and IL-1R were recently shown to associate and functionally depend on the large-conductance $\mathrm{Ca}^{2+}$-activated $\mathrm{K}^{+}$channel MaxiK ${ }^{32,33}$ Since this $\mathrm{K}^{+}$channel is abundantly expressed in macrophages, we could speculate that the activators MSU, PGN and probably imidazoquinoline activate the inflammasome via a MaxiK-mediated $\mathrm{K}^{+}$efflux. However, the use of MaxiK inhibitor paxilline did not inhibit caspase- 1 activation (data not shown), suggesting that different $\mathrm{K}^{+}$channelforming proteins are involved. One of the candidate proteins is pannexin-1, which interacts with the P2X7 receptor and forms large hemi-channels upon ATP addition. ${ }^{34}$ The presence of pannexin-1 is required for ATP, maitoxin and nigericininduced caspase- 1 activation, but its role in $\mathrm{K}^{+}$efflux is still poorly defined. ${ }^{34}$

Although NALP3 and Apaf-1 are only distantly related in terms of structure, both proteins form caspase-activating multiprotein complexes. Whereas NALP3 forms the inflammasome to activate caspase-1, Apaf- 1 forms the apoptosome, leading to the activation of caspase-9. Like the inflammasome, the apoptosome was found to be activated only under conditions of low intracellular $\mathrm{K}^{+}$; physiological concentrations almost fully inhibited cytochrome $c$-mediated Apaf-1 oligomerization. ${ }^{35}$ This $\mathrm{K}^{+}$dependence may be a highly conserved mechanism that prevents a spontaneous formation of caspase-activating platforms. Finally, NLRs have structural and functional homology to plant-resistant proteins, which are microbe-detecting proteins triggering an innate immune (hypersensitive) response. One of the genes implicated and essential for this response in plants is HLM1, which was found to be $\mathrm{K}^{+}$channel induced by pathogen infection. ${ }^{36}$ This suggests that controlling the $\mathrm{K}^{+}$concentrations is an important regulatory mechanism of inflammation.

In addition to $\mathrm{K}^{+}$, another intracellular compound seems to be required for NALP3 activation, namely ROS. Elevated ROS levels have been previously observed in ATP-treated macrophages and cells from stressed mice, which in both 
cases resulted in caspase- 1 activation. Although the pathway connecting ROS to inflammasome activation remains unknown, a downstream role of MAPK (p38 or ERK) was suggested. $^{29,37}$ Additional work is also required for the elucidation of the link between low $\mathrm{K}^{+}$and ROS.

In summary, the work presented here favors a model in which $\mathrm{K}^{+}$efflux is the common and specific trigger of NALP1 and NALP3 activation induced by all reported ligands, and implies the involvement of $\mathrm{K}^{+}$channel(s) whose exact nature and mode of activation remains to be identified.

\section{Materials and Methods}

Reagents. Nigericin and ATP were purchased from Sigma, Buchs, Switzerland, MSU and zVAD-fmk from Axxora, Lausen, Switzerland. Ultrapure LPS (E. coli 0111:B4), PGN, R837 and flagellin were obtained from Invivogen, Toulouse, France and bacterial RNA from Ambion, Rotkreuz, Switzerland. Poly(U), poly(l:C) and CpG were purchased from Axxora. Anthrax Lethal Factor and PA were purchased from List Biological Laboratories. For bacterial infection, S. typhimurium (gift from Robin Van Bruggen, Amsterdam), the E. coli Top10 strain and S. flexneri (kind gift from $P$ Sansonetti, Paris) were used. Anti-human cleaved IL-1 $\beta$ (2021L) was purchased from Cell Signaling and anti-IL-1 $\beta$ p35 is a sheep home-made antibody. The antibody against mouse IL-1 $\beta$ was a gift from Roberto Solari, Glaxo, Zug, Switzerland. The antibody against human caspase-1 (SC-622) was purchased from Santa Cruz, Nunningen, Switzerland and ASC (AL177) from Alexis, Lausen, Switzerland. ELISA for mouse and human cytokine detection were obtained from R\&D systems, Abingdon, UK and from BD Biosciences, Basel, Switzerland, respectively. All tissue culture reagents were bought from Invitrogen, Basel, Switzerland.

Mice. NALP3-/-, ASC-/- and IPAF-/- mice were described previously. ${ }^{21,27}$ NALP3 - /-, ASC - / - and IPAF-1- mice are in C57B6 background. For Anthrax LT stimulation, BALB/c mice were used.

Generation of THP1 cells expressing shRNA. THP1 stably expressing sh against lamin, NALP3, caspase-1 and ASC were obtained as follows. nt GATGCGGAAGCTCTTCAGTTTCA of the human ASC coding sequence, nt CAGGTTTGACTATCTGTTCT of the human NALP3 coding sequence, it GTGAAGAGATCCTTCTGTA of the $3^{\prime}$ UTR of the human caspase- 1 were inserted into pSUPER. The Pol III promoter shRNA cassettes from these vectors and from a lamin $A / C$-specific pSUPER control construct were inserted into the lentiviral vector pAB286.1, a derivative of pHR that contains a SV40-puromycin acetyl transferase cassette for antibiotic selection (lamin A/C-pSUPER and pAB286.1 were gifts of Richard Iggo, Lausanne, Switzerland). Second-generation packaging plasmids pMD2-VSVG and pCMV-R8.91 (Naldini et al., 1996) were used for lentivirus production and infection as described elsewhere. ${ }^{28}$

Cell preparation. Peritoneal macrophages were obtained by injecting 8- to 12 week-old mice of indicated genotypes i.p. with $10 \%$ thioglycollate solution, followed by peritoneal lavage 3 days later. Bone-marrow macrophages were derived from tibia and femoral bone marrow cells as described elsewhere. ${ }^{38}$

In a general way, macrophages were plated at a density of $10^{6}$ cells in 12-well dishes and non-adherent cells were removed after $2 \mathrm{~h}$. Cells were cultured in DMEM complemented with $10 \%$ FCS, $1 \mathrm{mM}$ sodium pyruvate, $100 \mathrm{UI} / \mathrm{ml}$ penicillin/ streptomycin and $2 \mathrm{mM} \mathrm{L-glutamine.}$

Mouse macrophages were primed overnight with $100 \mathrm{ng} / \mathrm{ml}$ ultra-pure LPS

THP1 cells were cultured in RPMI complemented with $10 \%$ FCS and $50 \mu \mathrm{M}$ 2-mercaptoethanol. For experiments, THP1 were differentiated $3 \mathrm{~h}$ with $0.5 \mu \mathrm{M}$ phorbol 12-myristate 13-acetate. Human monocytes were purified as described previously. ${ }^{9} \mathrm{~A}$ total of 800,000 cells were plated on 12-well plate overnight. The following morning, medium was replaced by Optimem and cells were treated for $6 \mathrm{~h}$ with Imiquimod/R837 10-15 $\mu \mathrm{g} / \mathrm{ml}$, PGN $20 \mu \mathrm{g} / \mathrm{ml}$, MSU $150 \mu \mathrm{g} / \mathrm{ml}$, nigericin $20 \mu \mathrm{M}$ and bacterial RNA 2-4 $\mu \mathrm{g} / \mathrm{ml}$, except ATP $5 \mathrm{~mm}$ that was added $30 \mathrm{~min}$ before the end of the stimulation. ZVAD was used at $50 \mu \mathrm{M}$. Bacteria were grown overnight at $37^{\circ} \mathrm{C}$ under shaking in tryptic soy broth for S. flexneri and S. typhimuriu, and in LB broth for $E$. coli. The day of infection, bacteria were diluted $1 / 50$, cultured for $2 \mathrm{~h}$, then washed and resuspended in Optimem. Macrophages were infected in Optimem for $1 \mathrm{~h}$, the cells were then washed and received Optimem complemented with gentamycin $(100 \mu \mathrm{g} / \mathrm{ml})$ for the remaining indicated time. $\mathrm{KCl}(130 \mathrm{~mm})$ was added at the same time than the antibiotic. Cells extracts and precipitated supernatants were analyzed by Western blot. $^{21}$

In vitro activation. Differentiated THP1 cells were pelleted and lysed with a syringe on ice in three volumes of hypotonic buffer as described previously. ${ }^{4}$ Inflammasome activation was induced by incubating the extracts at $37^{\circ} \mathrm{C}$ for $30 \mathrm{~min}$ and monitored by Western blot. Different concentrations of $\mathrm{KCl}$ were added to the extracts as described above. ASC immunoprecipitation was carried out using $1 \mu \mathrm{g}$ of ASC polyclonal antibody (AL177) at $+4^{\circ} \mathrm{C}$ overnight. Anti-Flag antibody (Sigma) was used as a control.

Acknowledgements. We thank C Mattmann, Rosa Castillo and Aubry Tardivel for technical support, and Helen Everet and Dan Muruve for the critical reading of the manuscript. We thank Sanjeev Mariathasan and Vishva M Dixit for the generous gift of the ASC and IPAF knock-out mice. This work was supported by grants of the Swiss National Science Foundation and the Commission of Technology and Innovation (CTI). VP and SP are supported by a Marie Curie Intra European Fellowship. $C D$ is supported by the Fondation pour la Recherche Médicale. FM is recipient of a Human Frontier Science fellowship.

1. Burns K, Martinon F, Tschopp J. New insights into the mechanism of IL-1beta maturation. Curr Opin Immunol 2003; 15: 26-30.

2. Martinon F, Tschopp J. Inflammatory caspases: linking an intracellular innate immune system to autoinflammatory diseases. Cell 2004; 117: 561-574

3. Martinon F, Tschopp J. NLRs join TLRs as innate sensors of pathogens. Trends Immunol 2005; 26: 447-454.

4. Martinon F, Burns K, Tschopp J. The inflammasome. A molecular platform triggering activation of inflammatory caspases and processing of prolL-beta. Mol Cell 2002; 10: 417.

5. Faustin B, Lartigue L, Bruey JM, Luciano F, Sergienko E, Bailly-Maitre B et al. Reconstituted NALP1 inflammasome reveals two-step mechanism of caspase-1 activation. Mol Cell 2007; 25: 713-724.

6. Martinon F, Tschopp J. Inflammatory caspases and inflammasomes: master switches of inflammation. Cell Death Differ 2007; 14: 10-22.

7. Ting J, Davis B. CATERPILLER: a novel gene family important in immunity, cell death, and diseases. Annu Rev Immunol 2005; 23: 387-414.

8. Inohara N, Chamaillard M, McDonald C, Nunez G. NOD-LRR proteins: role in hostmicrobial interactions and inflammatory disease. Annu Rev Biochem 2005; 74: 355-383.

9. Agostini L, Martinon F, Burns K, McDermott EM, Hawkins PN, Tschopp J. NALP3 forms an IL-1beta processing inflammasome with increased activity in Muckle-Wells autoinflammatory disorder. Immunity 2004; 20: 319-325

10. Grenier JM, Wang L, Manji GA, Huang WJ, Al-Garawi A, Kelly R et al. Functional screening of five PYPAF family members identifies PYPAF5 as a novel regulator of NF-kappaB and caspase-1. FEBS Lett 2002; 530: 73

11. Srinivasula SM, Poyet JL, Razmara M, Datta P, Zhang Z, Alnemri ES. The PYRIN-CARD protein ASC is an activating adaptor for caspase-1. J Biol Chem 2002; 277: 21119-21122.

12. Wang L, Manji G, Grenier JM, Al-Garawi A, Merriam S, Lora JM et al. PYPAF7: a nove PYRIN-containing Apaf1-like protein that regulates activation of NF-kB and caspase-1dependent cytokine processing. J Biol Chem 2002; 17: 29874-29880.

13. Franchi L, Amer A, Body-Malapel M, Kanneganti TD, Ozoren N, Jagirdar R et al. Cytosolic flagellin requires Ipaf for activation of caspase-1 and interleukin 1beta in salmonellainfected macrophages. Nat Immunol 2006; 7: 576-582.

14. Miao EA, Alpuche-Aranda CM, Dors M, Clark AE, Bader MW, Miller SI et al. Cytoplasmic flagellin activates caspase-1 and secretion of interleukin 1beta via Ipaf. Nat Immunol 2006; 7: 569-575.

15. Martinon F, Agostini L, Meylan E, Tschopp J. Identification of bacterial muramyl dipeptide as activator of the NALP3/cryopyrin inflammasome. Curr Biol 2004; 14: 1929-1934.

16. Kanneganti TD, Ozoren N, Body-Malapel M, Amer A, Park JH, Franchi L et al. Bacterial RNA and small antiviral compounds activate caspase-1 through cryopyrin/Nalp3. Nature 2006; 440: 233-236.

17. Kanneganti TD, Body-Malapel M, Amer A, Park JH, Whitfield J, Franchi L et al. Critical role for cryopyrin/Nalp3 in activation of caspase-1 in response to viral infection and doublestranded RNA. J Biol Chem 2006; 281: 36560-36568.

18. Gurcel L, Abrami L, Girardin S, Tschopp J, van der Goot FG. Caspase-1 activation of lipid metabolic pathways in response to bacterial pore-forming toxins promotes cell survival. Cell 2006; 126: 1135-1145.

19. Mariathasan S, Weiss DS, Newton K, McBride J, O'Rourke K, Roose-Girma M et al Cryopyrin activates the inflammasome in response to toxins and ATP. Nature 2006; 440 228-232.

20. Walev I, Reske K, Palmer M, Valeva A, Bhakdi S. Potassium-inhibited processing of IL-1beta in human monocytes. EMBO J 1995; 14: 1607-1614

21. Martinon F, Petrilli V, Mayor A, Tardivel A, Tschopp J. Gout-associated uric acid crystals activate the NALP3 inflammasome. Nature 2006; 440: 237-241. 
22. Sutterwala FS, Ogura Y, Szczepanik M, Lara-Tejero M, Lichtenberger GS, Grant EP et al. Critical role for NALP3/CIAS1/cryopyrin in innate and adaptive immunity through its regulation of caspase-1. Immunity 2006; $24: 317-327$

23. Watanabe H, Gaide O, Petrilli V, Martinon F, Contassot E, Roques S et al. Activation of the IL1beta-processing inflammasome is involved in contact hypersensitivity. J Invest Dermato/ 2007

24. Boyden ED, Dietrich WF. Nalp1b controls mouse macrophage susceptibility to anthrax lethal toxin. Nat Genet 2006; 38: 240-244.

25. Perregaux D, Gabel CA. Interleukin-1 beta maturation and release in response to ATP and nigericin. Evidence that potassium depletion mediated by these agents is a necessary and common feature of their activity. J Biol Chem 1994; 269: 15195-15203.

26. Colomar A, Marty V, Medina C, Combe C, Parnet P, Amedee T. Maturation and release of interleukin-1beta by lipopolysaccharide-primed mouse Schwann cells require the stimulation of P2X7 receptors. J Biol Chem 2003; 278: 30732-30740.

27. Mariathasan S, Newton K, Monack DM, Vucic D, French DM, Lee WP et al. Differential activation of the inflammasome by caspase-1adaptors ASC and Ipaf. Nature 2004; 430 : 213-218

28. Papin S, Cuenin S, Agostini L, Martinon F, Werner S, Beer HD et al. The SPRY domain of Pyrin, mutated in familial Mediterranean fever patients, interacts with inflammasome components and inhibits prolL-1beta processing. Cell Death Differ 2007.

29. Cruz CM, Rinna A, Forman HJ, Ventura AL, Persechini PM, Ojcius DM. ATP activates reactive oxygen species-dependent oxidative stress response and secretion of proinflammatory cytokines in macrophages. J Biol Chem 2007; 282: 2871-2879.

30. Hayashi F, Smith KD, Ozinsky A, Hawn TR, Yi EC, Goodlett DR et al. The innate immune response to bacterial flagellin is mediated by Toll-like receptor 5 . Nature 2001 410: $1099-1103$.
31. Scott $\mathrm{P}, \mathrm{Ma} \mathrm{H}$, Viriyakosol $\mathrm{S}$, Terkeltaub R, Liu-Bryan R. Engagement of CD14 mediates the inflammatory potential of monosodium urate crystals. J Immunol 2006; 177: 6370-6378.

32. Papavlassopoulos M, Stamme C, Thon L, Adam D, Hillemann D, Seydel U et al. MaxiK blockade selectively inhibits the lipopolysaccharide-induced I kappa B-alpha /NF-kappa B signaling pathway in macrophages. J Immunol 2006; 177: 4086-4093.

33. Scheel O, Papavlassopoulos M, Blunck R, Gebert A, Hartung T, Zahringer U et al. Cell activation by ligands of the toll-like receptor and interleukin-1 receptor family depends on the function of the large-conductance potassium channel MaxiK in human macrophages. Infect Immun 2006; 74: 4354-4356.

34. Pelegrin $P$, Surprenant A. Pannexin-1 couples to maitotoxin- and nigericin-induced interleukin-1 beta release through a dye uptake-independent pathway. J Biol Chem 2007; 282: 2386-2394.

35. Cain K, Langlais C, Sun XM, Brown DG, Cohen GM. Physiological concentrations of $\mathrm{K}+$ inhibit cytochrome c-dependent formation of the apoptosome. J Biol Chem 2001; 276: 41985-41990.

36. Balague C, Lin B, Alcon C, Flottes G, Malmstrom S, Kohler C et al. HLM1, an essential signaling component in the hypersensitive response, is a member of the cyclic nucleotidegated channel ion channel family. Plant Cell 2003; 15: 365-379.

37. Sekiyama A, Ueda H, Kashiwamura S, Sekiyama R, Takeda M, Rokutan $\mathrm{K}$ et al. A stressinduced, superoxide-mediated caspase-1 activation pathway causes plasma IL-18 upregulation. Immunity 2005; 22: 669-677.

38. Didierlaurent A, Brissoni B, Velin D, Aebi N, Tardivel A, Kaslin E et al. Tollip regulates proinflammatory responses to interleukin-1 and lipopolysaccharide. Mol Cell Biol 2006; 26: $735-742$.

Supplementary Information accompanies the paper on Cell Death and Differentiation website (http://www.nature.com/cdd) 